\title{
Age Specific Hepatitis B Surface Antigen (HBsAg) and Anti- HBs Seroprevalence among Patients Admitted to a State Hospital
}

\author{
Devlet Hastanesine Bașvuran Hastalarda Yașa Özgü Hepatit B Yüzey Antijeni ve Anti- \\ HBs Seroprevalansı
}

\author{
- Sibel Yıldız Kaya', ๑ Abdurrahman Kaya² \\ ${ }^{1}$ Sungurlu State Hospital, Clinic of Infectious Disease and Clinical Microbiology, Çorum, Turkey \\ 2/stanbul Training and Research Hospital, Clinic of Infectious Disease and Clinical Microbiology, Istanbul, Turkey
}

\begin{abstract}
Objectives: Chronic hepatitis B (CHB) infection affects 257 million people globally, Turkey is middle endemic region. According to public health data, about 2 million people in Turkey are considered to be positive for hepatitis B surface antigen (HBsAg). With effective vaccination programs, active and passive immunizations of newborns born from infected mothers and increased sanitation, the prevalence of HBsAg has declined over the past years. In Turkey, Hepatitis B virus vaccine has been included in the national vaccination schedule in 1998. In the study, our aim is to compare the seroprevalence of HBsAg and Anti-HBS by birth-date in Sungurlu State Hospital, Çorum.

Materials and Methods: The results of 1,486 patients who applied to our hospital were scanned retrospectively on the electronic system. The rate of $\mathrm{HBsAg}$ and anti-HBs seropositivity were compared by birth-date.

Results: Of 1486 cases, 737 were women and 749 were men. The median age was 38 (0-95 years). HBsAg positivity was $1.9 \%$ and anti-HBs positivity was $54.2 \%$. All of $27 \mathrm{HBsAg}$ positive patients were born before 1998. HBsAg positivity was found almost 3 times higher in the male population. Anti-HBs positivity was $41 \%$ in patients born before 1990, and 71\% in those born in 1998 and after. Conclusion: Immunization is very important and effective way in chronic hepatitis B infection control and prevention. The results of our study showed a significant decrease in $\mathrm{CHB}$ infection with the national vaccination program. It is very essential to administer HBV vaccination to all people, especially those at risk.

Keywords: HBsAg, anti-HBs, seroprevalence
\end{abstract}

\section{ÖZ}

Amaç: Kronik hepatit B (KHB) enfeksiyonu dünya genelinde 257 milyon kişiyi etkilemektedir, Türkiye orta endemiktir. Halk sağlığı verilerine göre, Türkiye'de yaklaşık 2 milyon kişinin hepatit B yüzey antijeni (HBsAg) pozitif olduğu düşünülmektedir. Etkili aşılama programları, HBsAg pozitif anneden doğan yeni-doğanların aktif ve pasif immünizasyonu ve artan hijyen koşullarıyla beraber son yıllarda HBsAg prevalansı azalmaktadır. Türkiye'de hepatit B aşısı 1998'de ulusal aşı programına alınmıştır. Bu çalışmada, Çorum Sungurlu Devlet Hastanesi'nde takip edilen hastalarda HBsAg ve anti-HBs seroprevalansının doğum ylına göre karşılaştırılması amaçlanmıştır. Gereç ve Yöntemler: Hastanemizde takip edilen 1.486 hastanın sonuçları retrospektif olarak elektronik sistem üzerinden tarandı. HBsAg ve anti-HBs seropozitifliği oranı doğum yılı ile karşılaştıııldı.

Bulgular: Bin dört yüz seksen altı hastanın 737'si kadın, 749'u ise erkekti. Ortanca yaş 38 (0-95 yaş) idi. HBsAg pozitifliği \% 1,9 antiHBs pozitifliği ise \%54,2 olarak bulundu. HBsAg pozitif bulunan 27 hastanın tamamı 1998 öncesi doğmuştu. HBsAg pozitifliği erkeklerde 3 kat daha fazla bulundu. Anti-HBs pozitifliği, 1990 öncesinde doğanlarda \%41 iken 1998 ve sonrasında doğanlarda $\% 71$ idi.

Sonuç: Bağışıklama, hepatit B enfeksiyonunun kontrolünde ve önlenmesinde çok önemli ve etkili bir yoldur. Çalışmamızın sonuçları, ulusal aşılama programı ile KHB enfeksiyonunda önemli bir azalma olduğunu göstermiştir. Hepatit B aşılamasının tüm insanlara özellikle de risk grubundakilere uygulanması çok önemlidir. Anahtar Kelimeler: HBsAg, anti-HBs, seroprevalans

Kaya SY, Abdurrahman Kaya A. Age Specific Hepatitis B Surface Antigen (HBsAg) and Anti-HBs Seroprevalence among Patients Admitted to a State Hospital. Viral Hepat J. 2020;26:85-87.

Address for Correspondence: Sibel Yıldız Kaya MD, Sungurlu State Hospital, Clinic of Infectious Disease and Clinical Microbiology, Çorum, Turkey 


\section{Introduction}

Chronic hepatitis $\mathrm{B}(\mathrm{CHB})$ infection is a common liver disease that affects 257 million people globally (1). The prevalence of hepatitis B surface antigen ( $\mathrm{HBs} A g$ ) ranges from 0.7 to $6.8 \%$ worldwide. Turkey is middle endemic region for $\mathrm{CHB}$ infection, according to World Health Organization (WHO) data.

With effective vaccination programs, active and passive immunizations of newborns born from infected mothers and increased sanitation, the prevalence of HBsAg has declined over the past years. However, it still remains one of the most important causes of liver cirrhosis and hepatocellular carcinoma (HCC) all over the world, especially in underdeveloped countries. In a systematic review between 1999-2009, HBsAg positivity was found to be $4.6 \%$ in our country (2). Currently, according to public health data, about 2 million people in Turkey (2\% of the population) are considered to be positive for HBsAg (3).

In Turkey, Hepatitis B virus (HBV) vaccine has been included in the national vaccination schedule in 1998. And catch-up immunization has been performed in primary schools. Thereby the vast majority of the generation born after 1990 has been vaccinated.

In the study, our aim is to compare the seroprevalence of HBsAg and anti-HBS by birth-date in Sungurlu State Hospital, Çorum.

\section{Materials and Methods}

The results of patients who applied to our hospital between January 2018 and October 2019 for any reason and who tested for HBsAg and anti-HBs were scanned retrospectively on the electronic system. As our study was retrospective, ethical approval and patients consent were not obtained. A total of 1486 patients were evaluated. The patients were divided into three groups according to their birth dates; 1. born before 1990 (918 cases), 2. born between 1991-1997 (216 cases), 3. born in 1998 and after (352 cases). The rate of HBsAg and Anti-HBs seropositivity were compared by birth-date.

\section{Statistical Analysis}

SPSS 21 program was used to analyze the data. Chi-square and Mann-Whitney U were used to compare categorical and continuous variables respectively. Post-hoc analysis with bonferroni correction was used for statistically significant results in the presence of more than two groups. P-value $\leq 0.05$ was considered significant.

\section{Results}

Of 1486 cases, 737 were women and 749 were men. The median age was 38 (0-95 years). HBsAg positivity was 1.9\% (29) and anti-HBs positivity was 54.2\% (805). While 27 of the HBsAg positive patients were born before 1990, 2 patients were born in between 1990-1998. HBsAg positivity was found almost 3 times higher in the male population (Table 1). Of 29 patients with $\mathrm{HBsAg}$ positivity, 21 were male and 8 were female, the difference between the genders was statistically significant $(p=0.02)$. Eight patients were inactive $\mathrm{HBsAg}$ carriers and 7 were under antiviral treatment with the diagnosis of $\mathrm{CHB}$. Fourteen patients (48\%) were without follow-up. Anti-HBs positivity was $41 \%$ in patients born before 1990, and $71 \%$ in those born in 1998 and after (p>0.001). Anti-HBs positivity was slightly higher in men (Table 1), but not statistically significant $(p=0.10)$. Anti-HCV positivity was $0.4 \%(6 / 1447)$ and anti-HIV positivity was $0.1 \%$ (2/1332).

\section{Discussion}

With effective vaccination programs, although the incidence of HBsAg has been decreasing all over the world, CHB is still the most important cause of liver cirrhosis and HCC-related deaths. It is estimated 887.000 deaths per year (1). In Turkey, approximately $2 \%$ of the population are considered to be HBsAg positive, and 40-50\% of liver transplantations between 2012 and 2016 were caused by complication of HBV infection $(3,4)$. On the other hand, as the disease remains silent without having complication, most patients are unaware of their illness. While, only $10.5 \%$ of $\mathrm{HBsAg}$ positive individuals are thought to be aware of their disease worldwide, this rate was found $12 \%$ in a study in Turkey $(1,5)$. In our study, 14 of 29 HBsAg positive patients (48\%) did not have CHB follow-up.

Vaccination is the most effective way to control and prevent the disease. HBV vaccination provides $98-100 \%$ protection from HBV infection. In 1992, WHO called for vaccination of infants against HBV worldwide, thereafter, vaccination programs for HBV have been conducted in most countries. In Turkey, HBV vaccine has been included in the national vaccination program since 1998. According to Public Health Agency data, the rate of vaccination for hepatitis B increased from 64\% in 1999 to $98 \%$ in 2018 in Turkey. While the incidence of acute hepatitis B was 4-6 per 100.000 in 1990, it was reported as 1.9 per 100.000 in 2017 in our country. Under the age of 15 , this rate has decreased to less than 1 per 100.000 (3).

$\mathrm{HBV}$ vaccine is the first vaccine that prevent from cancer. In a study published in 1997 in Taiwan, it was observed that there

Table 1. Distribution of hepatitis B surface antigen ( $\mathrm{HBsAg}$ ) and anti-HBs positivity by gender and birth-year

\begin{tabular}{|l|l|l|l|l|}
\hline \multicolumn{2}{|l|}{} & Number of cases & HBsAg (n, \%) & Anti-HBs (n, \%) \\
\hline \multirow{3}{*}{ Gender } & Female & 737 & $8(1)$ & $385(52)$ \\
\cline { 2 - 5 } & Male & 749 & $21(2.8)$ & $420(56)$ \\
\hline \multirow{3}{*}{ Birth-year } & $\leq 1989$ & 918 & $27(2)$ & $383(41)$ \\
\cline { 2 - 5 } & $1990-1997$ & 216 & $2(0.9)$ & $169(78)$ \\
\cline { 2 - 5 } & $\geq 1998$ & 352 & $0(0)$ & $253(71)$ \\
\hline Total & - & 1486 & $29(1.9)$ & $805(54.2)$ \\
\hline HBsAg: Hepatitis B surface antigen & & & \\
\hline
\end{tabular}


was a significant decrease in childhood HCC cases after the HBV vaccination program (6). In another study from Alaska, it was emphasized that there was a significant decrease in acute hepatitis $\mathrm{B}$ and $\mathrm{HCC}$ cases in childhood after the national vaccination program (7).

The results of our study showed a significant decrease in $\mathrm{CHB}$ infection with the national vaccination program. HBsAg positivity was found $1.9 \%$ in our study group, and all patients were born before 1998. The results were consistent with the rate of our country (2\%). HBsAg positivity was found $2.5 \%$ in a study including 61.943 volunteers from 73 provinces (8). In another study from Turkey, HBsAg was found positive in $4.75 \%$ of 58.752 cases and $97 \%$ of the cases were born before 1998 (9). In a review HBsAg positivity in pregnant women between 1975-2016, it was seen that HBsAg positivity varied between 1.2-19.2\%. This rate was decreased to 1.2-5.2\% after 2010 (10).

While the anti-HBs positivity was found to be about $70 \%$ in the first 3 decades, it decreased below $40 \%$ in the subsequent decades. As of the $7^{\text {th }}$ decade, it seems that anti-HBs positivity started to increase again (Table 2). This increase is thought to be associated with increased disease contact. In a study published in 2016, similar to our study, anti-HBs positivity was $85.56 \%$ in the 0-12 age group and $56.4 \%$ in the 13-20 age group, it decreased to $20 \%$ within the 20 years. In those over 50 years old, anti-HBs positivity increased again and rises above 40\% (11).

\section{Study Limitations}

This study had some limitations including retrospective design, low number of cases and unknown of patients anti-HBc lgG status. Prospective studies are needed to better demonstrate these findings.

\section{Conclusion}

HBV infection is a communicable disease that can have fatal complications. Immunization is very important and effective way in its control and prevention. With national vaccination program, it is clear that the incidence of the disease has decreased considerably.

\begin{tabular}{|l|l|l|}
\hline \multicolumn{3}{|l|}{ Table 2. Distribution of anti-hepatitis B surface positivity by ages } \\
\hline Age & Number of cases & Anti-HBs positivity (n, \%) \\
\hline $0-10$ & 140 & $100(71.4)$ \\
\hline $11-20$ & 181 & $125(69.1)$ \\
\hline $21-30$ & 274 & $203(74.1)$ \\
\hline $31-40$ & 204 & $76(37.3)$ \\
\hline $41-50$ & 179 & $59(33)$ \\
\hline $51-60$ & 157 & $60(38.2)$ \\
\hline $61-70$ & 167 & $79(47.3)$ \\
\hline $71-80$ & 128 & $67(52.3)$ \\
\hline $81-90$ & 48 & $30(62.5)$ \\
\hline $91-100$ & 8 & $6(75)$ \\
\hline Total & 1486 & $805(54.2)$ \\
\hline HBs: Hepatitis b surface & \\
\hline
\end{tabular}

Therefore, it is very essential to administer HBV vaccination to all people, especially those at risk.

\section{Ethics}

Ethics Committee Approval: As our study was retrospective, ethical approval was not obtained.

Informed Consent: Patient consent was not obtained.

Peer-review: Internally peer-reviewed.

\section{Authorship Contributions}

Surgical and Medical Practices: S.Y.K, A.K., Concept: S.Y.K, A.K., Design: S.Y.K, A.K., Data Collection or Processing: S.Y.K, A.K., Analysis or Interpretation: S.Y.K, A.K., Literature Search: S.Y.K, A.K., Writing: S.Y.K, A.K.

Conflict of Interest: Authors declare no conflict of interest.

Financial Disclosure: There was no aid and sponsor for this study.

\section{References}

1. Hepatitis B fact sheet. In: World Health Organization:media centre. Update: 18 July 2019. https://www.who.int/news-room/ fact-sheets/detail/hepatitis-b (Date of access: 05.02.2020).

2. Toy $M$, Önder FO, Wörmann $T$, Bozdayi AM, Schalm SW, Borsboom GJ, van Rosmalen J, Richardus JH, Yurdaydin C. Ageand region-specific hepatitis $B$ prevalence in Turkey estimated using generalized linear mixed models: A systematic review. BMC Infect Dis. 2011;11:337.

3. Irmak H, Yardım N, Keklik K, Temel F Türkiye viral hepatit önleme ve kontrol programı 2018-2023. Sağlık Bakanlığı Yayın No: 1102, Ankara, 2018

4. Nakil Sayıları - TTDIS Karar Destek Sistemi. Organ, Doku Nakli ve Diyaliz Hizmetleri Daire Bașkanlığı. https://organkds.saglik. gov.tr/KamuyaAcikRapor.aspx?q=ORGANNAKLI (erişim tarihi: 11.03.2018).

5. Tozun N, Ozdogan O, Cakaloglu Y, Idilman R, Karasu Z, Akarca U, Kaymakoglu S, Ergonul O. Seroprevalence of hepatitis B and C virus infections and risk factors in Turkey: A fieldwork TURHEP study. Clin Microbiol Infect. 2015;21:1020-1026.

6. Chang MH, Chen CJ, Lai MS, Hsu HM, Wu TC, Kong MS, Liang DC, Shau WY, Chen DS. Universal hepatitis B vaccination in Taiwan and the incidence of hepatocellular carcinoma in children. N Engl J Med. 1997;336:1855-1859.

7. McMahon BJ, Bulkow LR, Singleton RJ, Williams J, Snowball M, Homan C, Parkinson AJ. Elimination of hepatocellular carcinoma and acute hepatitis B in children 25 years after a hepatitis B newborn and catch-up immunization program. Hepatology. 2011; 54:801-807.

8. Tosun S, Balık I, Tabak F, Saltoğlu N, Örmeci N, Şencan I, Öztoprak N, Gürbüz Y, Olut Al. Evaluation of risk factors associated with hbsag and anti-hcv seropositivity: Results of a nationwide population based epidemiological survey study in Turkey. Mediterr J Infect Microb Antimicrob. 2018;7:34.

9. Bayındır Bilman F. HBsAg, anti-HCV and anti-HIV Seroprevalence Among Patients Admitted to State Hospital between 2014 and 2018. Mediterr J Infect Microbes Antimicrob. 2019;8:14.

10. Bakar RZ, Dane B. Gebelerde hepatit B seropozitifliği ve Türk literatürüne bir bakış. Perinatoloji Derg. 2016;24:83-88.

11. Guclu E. Ogutlu A. Karabay O. A study on the age-related changes in hepatitis B and C virus serology. Eurasian J Med. 2016;48:3741. 